\title{
Towards an intellectual history of evolutionary economics: competition and struggle versus cooperation and mutual aid
}

\author{
Rumo a uma história intelectual da economia evolucionária: \\ competição e luta versus cooperação e ajuda mútua
}

JOHN HALL

SVETLANA KIRDINA-CHANDLER*

RESUMO: Nossa investigação considera as origens da Economia Evolutiva reintroduzindo um debate que teve lugar na Rússia no século XIX e início do século XX. Respostas ao Origem das Espécies de Charles Darwin são consideradas, especialmente as críticas que enfatizam a ênfase de Darwin na competição e na luta na seleção natural, que podem ser traçadas diretamente a Thomas Robert Malthus. Considerando contribuições desafiadoras feitas por vários eruditos russos, colocamos uma ênfase especial no foco de Peter Kropotkin na cooperação e na "ajuda mútua" na seleção natural e na evolução. Em seguida, especulamos sobre a semelhança encontrada nas visões evolucionistas avançadas por Kropotkin e seu contemporâneo americano, Thorstein Veblen.

PALAVRAS-CHAVE: Charles Darwin; economia evolucionária; ajuda mútua; Peter Kropotkin; Thomas Robert Malthus; Thorstein Veblen.

ABSTRACT: Our inquiry considers the origins of Evolutionary Economics by reintroducing a debate that took place in Russia in the $19^{\text {th }}$ and early $20^{\text {th }}$ century. Responses to Charles Darwin's The Origin of Species are considered, especially critiques stressing Darwin's emphasis upon competition and struggle in natural selection, that can be traced directly to Thomas Robert Malthus. Considering challenging contributions made by several Russian scholars, we place special emphasis upon Peter Kropotkin's focus on cooperation and "mutual aid" in natural selection and evolution. We then speculate upon the commonality found in the evolutionary views advanced by Kropotkin and his American contemporary, Thorstein Veblen.

KEYWORDS: Charles Darwin; Evolutionary Economics; mutual aid; Peter Kropotkin; Thomas Robert Malthus; Thorstein Veblen.

JEL Classification: B1; B2; B3.

\footnotetext{
* Professor of Economics and International Studies; Portland State University; Oregon, USA. E-mail: hallj@pdx.edu; Head of the Sub-Division for the Evolution of Social and Economic Systems; Institute of Economics; Russian Academy of Sciences; Moscow, Russia. E-mail kirdina@bk.ru. Submitted: 12/ April/2016; Approved: 19/August/2016.
} 
Debates may prove fruitful for Economic Science, as various points of view can be advanced that shed light on subjects of inquiry and concern. While some debates are effectively settled, others remain ongoing as fundamental issues go unresolved. Our understanding is that a failure to resolve a debate proves more likely when ideology enters in and compromises earnest scientific inquiry.

Our way of exploring the intellectual history of Evolutionary Economics is to reconsider a debate that took place in Russia in the second-half of the $19^{\text {th }}$ and the first two decades of the $20^{\text {th }}$ century. The debate participants were dealing with some pressing questions. Namely, does competition and struggle serve as the main variables initiating and driving natural selection and evolution? Or is cooperation and mutual aid the driver? While these registered as burning questions to Russian scientists many decades back, we think these questions remain fundamental for those interested in understanding the intellectual origins of this field of inquiry we know as Evolutionary Economics.

\section{DARWIN'S IMPORTANCE}

Our sense is that exploring this Russian debate aids in understanding the seminal ideas advanced by Charles Darwin. What we can note is that Darwin's ideas regarding natural selection hardly moved beyond biological processes. We can, however, note an exception. In The Descent of Man [1871] he clearly devotes attention to relationships between natural selection and civilized societies. However Darwin (1871, pp. 158-184) emphasized; that as a process natural selection sheds little light upon human communities, at least not in the manner that it does upon the plant and animal kingdoms. ${ }^{1}$

Then there arises a problem related to the distortion and misuse of Darwin's thinking as it has been applied to the societal sphere. Namely, we can find a noxious tradition established by social Darwinists with proclivities to emphasize connections between race, ethnicity, and competition. Typically, their thinking seeks to reinforce a status quo related to the dominance of those racial and ethnic groups composing nations that display successes in advancing industrialization. Then technological prowess and relatively high per capita incomes are touted as key measures of evolutionary superiority. Eduard Kolchinsky (2014, p. 4) helps us to understand this tendency to instrumentalize Darwin's thinking by noting evolution as " [...] one of the most ideological of sciences."

Our research suggests that indeed place can play a role in the development of ideas. After his grand voyages Darwin formulated his thoughts while based back in Great Britain during a period in which this powerful nation-state had established itself at the center of an extensive and still expanding empire spanning the globe.

\footnotetext{
${ }^{1}$ See especially Chapter V, “On the Development of the Intellectual and Moral Faculties during Primeval and Civilized Times,” pp. 158-184.
} 
In 1859 at the time that Darwin published his monumental The Origin of Species, his country registered as one of the most densely populated in all of Europe, and competition for space contributed to pressures encouraging outmigration to colonies and former colonies. Economic competition also characterized the realm of family-owned businesses that comprised the industrializing economy during this era described by the term laissez-faire. The character of this era is reflected in Economic Science through Alfred Marshall's understanding of the perfectly competitive firm. A market structure typified as "Perfect Competition" became the primary focus of inquiry in the first and later editions of his textbook classic, Principles of Economics, the first edition appearing in 1890.

In contrast to Darwin's Britain, the Russian empire included a vast and sparsely populated geographic area that stretched beyond Europe's boundary at the Ural Mountains - all the way across continental Asia to the Pacific. Russia, and especially the vast areas of Siberia, offered fundamentally different environments and places from which hypotheses regarding natural selection and evolution could be drawn.

Research of Daniel Todes emphasizes how place and related variables like population density could indeed bear influence on scientific inquiry that sought to establish the forces and variables at work driving natural selection and evolution. In Darwin Without Malthus: The Struggle for Existence in Russian Evolutionary Thought (1989), Todes considers how a wide-range of Russian thinkers responded to Darwin's ideas. Reactions were indeed mixed. However, what Todes emphasizes is how Russia's distance from major European centers, the relatively low population density related to her vastness and that can be found especially in the landscapes of Siberia, could serve not only as the sources for reactions to Darwin's thinking posed by selected Russian thinkers, but could also provide inspiration and thereby generate alternative understandings of what drives natural selection and evolution.

\section{DARWIN, MALTHUS AND THE “STRUGGLE FOR EXISTENCE”}

Of particular concern to Todes are key ideas advanced by Thomas Robert Malthus presented in various editions of An Essay on the Principles of Population published just before and during the first decade of the $19^{\text {th }}$ century. We can note that Malthus' thinking benefited from wide-circulation several decades prior to Darwin's arrival on Britain's scientific scene, thereby providing a foundation for the intellectual and cultural environment for his theorizing. The powerful influence of Malthus' ideas are obviously integrated into Darwin's understanding of the importance of the term "struggle for existence," what registers as the title and also the subject matter of Chapter Three of his Origin.

As a way for considering Darwin's approach to knowledge, we can rely upon the concept of an "episteme" introduced by the $20^{\text {th }}$ century French thinker Michel Foucault. In Foucault's Archeology of Political Economy (2010) author Iara Vigo de Lima defines Foucault's notion of an episteme as a structure of relations that 
includes collective frames of reference. These collective frames of reference may then serve as an approach to knowledge which combines with an ontology, and that can be enhanced through the study of linguistics and signs. In Foucault's understanding, an episteme offers context so pervasive as to suggest a widely shared - if not universal - understanding of reality.

According to the view of Lima (2010, pp. 102-105), Adam Smith's Inquiry published towards the end of the $18^{\text {th }}$ century registers as emblematic of a transition to a Modern Episteme that she notes - following Foucault's lead - as the "Age of History." In this particular age "man" (or humans) becomes the object of knowledge and inquiry and this development is noted to offer a foundation for the emergence of social sciences that include political economy. ${ }^{2}$ Our understanding is that with the establishment of this Modern Episteme, the Reverend Malthus takes an early and rudimentary scientific approach for constructing and advancing his ideas on population and its relation to the means of subsistence. To do so Malthus applies two differing mathematical formulas in order to characterize his understanding of problems associated with geometrical increases in population relative to arithmetic increases in food supply.

The literature suggests that Malthus' interacting with David Ricardo through their ongoing exchange of letters helped to integrate what is widely known as the Malthusian Doomsday Prophecy into the foundations of political economy inquiry. ${ }^{3}$ It appears that Malthus' notion of the importance of "checks on population" serves as a key and unquestioned assumption underlying this Modern Episteme into which Darwin was born in 1809.

In our interpretation, what Malthus advanced is an inherently moralistic position, positing that the passion between the sexes remains constant, while the means of subsistence that a worker needs to purchase in order to nourish his children can change. If wages or their purchasing power were to fall, then children could perish from lack of nutrition. For Malthus, the problem is that more are born than will survive. In our understanding this Malthusian kernel of thinking became integral to the Modern Episteme into which Darwin arrived as a creative inquirer. In this manner Malthus' thinking appears to have affected Darwin's frames of reference

\footnotetext{
${ }^{2}$ Lima (2010, p. 79) emphasizes three episteme that Foucault develops. The first is known as a pre-classical episteme that is termed the "Age of Resemblance," and this time frame extends up through the $16^{\text {th }}$ century. God is noted as the object of knowledge. Signs are thought given by God and knowledge is communicated by analogy. The second episteme is dubbed the "Age of Representation" and spans the $17^{\text {th }}$ and 18 th centuries. Nature is taken as the object of knowledge and signs serve as representations. In this age human efforts go toward explaining the world by use of analysis and by imposing order. For the third episteme, Lima (clarifying Foucault's thinking) equates the "Age of History" with the Modern Episteme.

${ }^{3}$ Ricardo integrated Malthus' understanding of checks on population into what he termed as the "iron law" of wages. Writing some decades after Ricardo, Karl Marx relies upon Ricardo's understanding of wages in order to develop his labor theory of value, what serves as the cornerstone of his analysis of $19^{\text {th }}$ century capitalist production.
} 
as he undertook his hypothesizing and theorizing regarding natural selection and evolution taking place in the plant and animal kingdoms.

If many are born and not all survive, then what contributes towards their survival? To quote from his Origin, Darwin $(1979$, p. 118) stresses “[...] the geometrical tendency to increase must be checked by destruction at some period of life." Darwin (1979, p. 117) can be quoted:

Hence, as more individuals are produced than can possibly survive, there must in every case be a struggle for existence, either one individual with another of the same species, or with the individuals of distinct species, or with physical conditions of life. It is the doctrine of Malthus applied with manifold force to the whole animal and vegetable kingdoms; for in this case there can be no artificial increase of food, and no prudential restraint from marriage. (Authors' emphasis)

Our understanding is that Darwin relied upon Malthus' assumption regarding checks on human population for Britain's laboring class and carried this key notion over to his hypothesizing about plants and animals. What Darwin introduces as natural selection and infers as evolution can be added on and integrated as the corollary to complete what Malthus regarded as checks on human populations. Namely, if indeed many are born, then those creatures benefiting from favorable adaptions and variations might then also benefit from enhanced chances of survival and of producing progeny that carry the variations into sequential generations. In this sense Darwin's understanding of natural selection and evolution carries the birthmarks of Malthus' thinking. What seems scientifically troublesome is that Darwin offers no qualifications or critical appraisals as he readily shifts from borrowing uncritically from Malthus' strong position and theorizing on the plight of members of Britain's laboring class, to his own theorizing about biological and botanical processes, past, present and future.

\section{CRITICAL REACTIONS TO DARWIN'S THINKING IN RUSSIA}

As noted above, Darwin's Origin first appeared in 1859. Soon thereafter and as early as 1861, the Russian journal Biblioteka dlya chteniya (Library for Reading) published an essay stretching over two hundred pages in length that introduced and dealt with Darwin's novel ideas. On this subject Alexander Vučinich (1989, p. 17) stresses that just two years later - in 1863 - the first issue of Russky Vestnik (Russian Herald) published an article by Sergei Rachinsky entitled: "Flowers and Insects.” This well-established Professor of Botany at Moscow University explained Darwin's theoretical structure in a language that was accessible to the general, reading public. Furthermore, Rachinsky (1863, p. 392) assessed Darwin's Origins as "[...] one of the most brilliant books ever written in the natural sciences." One year later, in 1864, Rachinsky produced the first Russian translation of Origins. One 
measurable outcome is that during the 1870s and 1880s in Russia, Yakor Gall (1976) emphasizes that Darwin's thinking became firmly entrenched in the full range of natural sciences, especially. Alexander Vučinich $(1989,31)$ stresses that in these decades near the end of the $19^{\text {th }}$ century, many scholars “... made Darwin's theory the point of departure in wide areas of scientific research." With time, Darwin's novel ideas were introduced more broadly, and his seminal ideas expanded and penetrated not only the social sciences in Russia, but also philosophical, theological, and even ethical discourse.

Towards the end of the $19^{\text {th }}$ century Russian scholars shared a belief that scientific inquiry could serve as the driver for social progress and humanitarian values. In Russia, Darwin's contributions were broadly viewed as a body of positive knowledge that served to emancipate the human mind from the tyranny of prejudice and superstition. Voicing the appreciation of many scholars, Nikolay Danilevsky (18859 , vol. 1) stressed that: "Darwinism changed not only our common-sense and scientific ideas but also our world view."

Following this line of thinking, Georgievsky and Khakhina $(1996,9)$ stress that Russia is rightly known as "the second homeland of Darwinism." Though Darwin's thinking became widely known and also deeply revered, critiques were nevertheless introduced; with some seeking to clarify and others intending to challenge, discredit and in this manner undermine his influence. Silvano Tagliagambe (1983, p. 257) understands this development and he stresses that in Russia during the last decades of the $19^{\text {th }}$ century, Darwin's theorizing served as a powerful catalyst for cultural and political debate. With this inquiry we shall shy away from analysing the main positions found in this debate as these apply to biology and botany, for the several positions are considered in depth by Georgievsky and Khakhina (1996, pp. 81-91), as well as by Zavadsky (1973). In addition, Todes (1989) and Vučinich (1989) offer relevant perspectives of outsiders looking into these debates taking place within Russia.

What remains important to emphasize is that with time Darwin's ideas drew vociferous criticism, as many Russian scientists harboured deep-seated doubts regarding what his thinking sought to advance. What especially sparked their ire was the application of biological principles of natural selection and evolution to Russia's social and cultural fabric. As Darwin's thinking became the target for attacks, many of the critics united in a determined effort to expose what they viewed as some of the flaws in both the substance and the logic of his theory. Conflicting values appear to have goaded his Russian critics.

While Darwin's thinking was clearly rooted in positivism and also materialism, its substance represented the antithesis of dominant values underpinning Russian society during these key decades in the late $19^{\text {th }}$ and early $20^{\text {th }}$ century. Historian and writer Mikhail Pogodin (1873, p. 105) purports that Darwin's ideas were both incorrect in substance and non-Russian in their soul. This aversion to and rejection of Darwin's ideas, reflected in Pogodin's critique, were also connected with ongoing antagonisms between Russia and the West (see: Sorokin, p. 1963, 52). In this vein, authors like Nikolay Danilevsky $(1888,1885-89)$ stressed that Russians tend- 
ed to harbour opposition to Darwin's thinking on philosophical and cultural grounds, and their railings against Darwin's ideas could be considered conscious as well as unconscious historical instincts.

The general reaction that we can note is that representatives of different political groups and ideological wings focused on Darwin's Malthusian influences that we carefully cited above. The critics tended to align with groups, and the key groups to consider were known and labelled as Slavophiles, Liberals, Populists and Anarchists.

To offer some insights into these groups: Slavophiles were rooted in an intellectual Russian movement that was expanding during the late $19^{\text {th }}$ and early $20^{\text {th }}$ century. The Slavophiles proclaimed their opposition to the powerful influences coming out of Western Europe. As an alternative, the Slavophiles promoted a nativist Russian development based upon values and institutions rooted in early national history.

In contrast to the Slavophiles, in the late $19^{\text {th }}$ century members of a group known as "Liberals" professed a wholly different orientation. They advocated that Russia continue her orientation towards Europe and act to model development after more advanced European countries, like Germany and France.

A third group known as "Populists" were also known as Narodniki, and narodas the root of this Russian word means "folk." The Narodniki emerged as a social and political movement in Russia and exerted strong political influences between the Years 1869 to 1897, especially. Members of the Narodniki rallied around such slogans as: "going to the people" and "education of common people."

Finally, we can note a fourth group labelled as "Anarchists." Proponents of anarchism were associated with developing key ideas that were opposed to state structures; like autocracy, monarchy; and after 1917, the emergent power of a Bolshevik controlled state apparatus.

Vučinich offers us some insights into how members of these groups related to Darwin's thinking. For example, he considers one Nikolay Mikhailovsky as a leader of the populist-oriented Narodniki. Vučinich $(1989$, p. 333) teaches us that Mikhailovsky advanced a critique that focused on Darwin's emphases upon competition and "struggle for existence." He argued that Darwin's understandings failed in reflecting true Russian concerns, as this notion of "struggle" was associated with moral and political orientations more characteristic of Western Europe's capitalistic values.

In addition, Nikolay Danilevsky authored a major study with the simple title: Darwinism, with the added subtitle, A Critical Study. In the view of Vučinich (1989, p. 126), Danilevsky offered a summary of the anti-Darwin critiques cropping up in the late $19^{\text {th }}$ century. In particular, Danilevsky took Darwin to task over his uses of the data upon which he based his understanding of organic evolution. Then Danilevsky relied upon the data he had collected in an effort to undermine Darwin's main points that he had rejected.

Representing the liberal and pro-western group, as another point of critique Nikolay Chernyshevsky (1886) defended the idea of organic evolution, but argued 
that the mechanisms for "checks on population" failed to contribute in measurable ways to organic evolution as a progressive process. It was Chernyshevsky who advocated going beyond what Darwin had set up as Malthusian limitations.

Russian populists such as Nikolay Nozhin and Nikolay Mikhailovsky also argued that the weaknesses in Darwin's thinking related to his reliance upon the notion of struggle for existence as the driver of natural selection and evolution. For these thinkers, this notion of struggle served not as an instrument for species development, but as a pathological phenomenon. In particular, Nozhin (1866, p. 175) reduced Darwin's contributions to a "theory of a bourgeois naturalist." Challenging Darwin, Nozhin formulated a law stressing that animals are united by common interests and cooperation, and are not split by a division of labour and competition. Vučinich $(1989$, p. 332) emphasized that Nozhin's "Law" served as the point of argument for Mikhailovshky's sociological criticism of Darwin's thinking.

With contributions of these Russian authors and their political orientations and associated groups considered, we can now note that Prince Peter Alexeievich Kropotkin appears to have generated a particularly constructive criticism of Darwin's reliance upon Malthus' key ideas that were formed into the notion of struggle for existence.

\section{KROPOTKIN ON MUTUAL AID}

Of contributors to what we are introducing as a major Russian debate taking place many decades back, we can note that Peter Kropotkin displayed an unwavering and deep-seated respect for Darwin's thinking. He even regarded the theory of natural selection as "[...] perhaps the most brilliant scientific generalization of the [19 $\left.{ }^{\text {th }}\right]$ century" (Avrich, 1988, p. 58). In addition, Kropotkin accepted that the struggle for existence played an important role in the evolution of species, and he extended his thinking even further, arguing that life is a struggle; and in this struggle indeed the fittest survive. However, in his foundational book, Mutual Aid: A Factor of Evolution [1902] (2006), Kropotkin criticized Darwin's emphasizing competition and the struggle for existence as valid and universal laws. In their place he introduced the "Law of Mutual Aid," and carried its logic far beyond the plant and animal kingdoms to also consider human relations and the foundations for the emergence of moral instincts and even ethical behaviour. ${ }^{4}$ In his speculating Kro-

\footnotetext{
${ }^{4}$ Furthering ideas first advanced by Karl Kessler (1880) regarding mutual aid as a law found in Nature, Kropotkin began to analyse data collected while on expeditions to eastern Siberia in 1864-65. Kropotkin's main ideas on the issue were introduced between 1890 and 1896 when he lived in exile in Great Britain, and through a series of essays appearing in a British monthly literary magazine known as Nineteenth Century. In his articles, Kropotkin criticized what he labelled as the "struggle-for-life" manifesto advanced by Thomas Huxley in his 1888 article: "Struggle for Existence and its Bearing upon Man." In 1902 Kropotkin summarized his articles in the book Mutual Aid: A Factor of Evolution published in London by William Heinemann. Kropotkin (2006, p. xviii) emphasizes that: "It is a book
} 
potkin supposed that mutual aid would be considered, not only as an argument in favor of a pre-human origin of moral instincts, but also as a Law of Nature and therefore as a factor in social evolution. Kropotkin (2006, p. 244) argued strongly regarding the importance of mutual aid and juxtaposed his understanding to what he viewed as an over-emphasis upon individualism, arguing that:

$[\ldots][t]$ he animal species, in which individual struggle has been reduced to its narrowest limits, and the practice of mutual aid has attained the greatest development, are invariably the most numerous, the most prosperous, and the most open to further progress.

Kropotkin offers the view that when considering ethical progress, indeed mutual aid - not mutual struggle and fierce competition - plays the leading role. It appears that ideas concerning mutual aid in the sense advanced by Kropotkin became so widespread and also so widely accepted and endorsed throughout Russia's intellectual scene, that in the view of Georgievsky and Khakhina $(1996$, p. 97) this set of ideas contributed to the situation that speculating and hypothesizing in the social Darwinist tradition never took root. It remains important to note that Kropotkin $(2006$, p. 247) carried his ideas to the limit, singling out the importance of mutual aid and stressing this as the variable that would lead our societies to a "loftier evolution."

\section{PETER KROPOTKIN AND THORSTEIN VEBLEN}

The contributions and emphases of Peter Kropotkin clearly need to be considered when examining the Russian debate and how Darwin was dealt with in the efforts to advance evolutionary thinking. However, when considering the rise of Evolutionary Economics as a field for inquiry, we have also to recognize Thorstein Veblen for his role. In effect, the publication of his seminal article laid the scientific foundation for Evolutionary Economics as a bon a fide field within Economic Science. In 1898 the prestigious Quarterly Journal of Economics featured Veblen's "Why is Economics not an Evolutionary Science?" With this article he offered a critique of the neoclassical approach stemming from Alfred Marshall that dominated economics at the turn of the $20^{\text {th }}$ century in the West. In place of a mechanical and marginalist approach to economic analysis, Veblen emphasized the importance of a concatenation, and this suggests a connectedness between and among variables that come together and play roles in engendering economic and societal outcomes. Veblen also added to our vocabulary and understanding of economic and social processes the term and associated meanings of cumulative causation. In

on the law of Mutual Aid, viewed at as one of the chief factors of evolution - not on all factors of evolution and their respective values; and this first book had to be written, before the latter could become possible." 
his efforts to establish an evolutionary approach to economics, Veblen clearly broadened the scope for inquiry as he emphasized relations and connections not only between physical variables that were well known to economists, but he also provided a way for our considering metaphysical variables and their interfacing with physical variables in generating outcomes.

When considering Kropotkin and Veblen as two creative thinkers who advanced inquiry into evolutionary thinking, we can cite their similarities as well as differences. To start into this comparing and contrasting, we can note that Peter Kropotkin was born in 1842 in Moscow, and fifteen years later Thorstein Veblen was born in 1857 in Wisconsin, USA. Though arriving in different parts of the world about fifteen years apart, both Kropotkin and Veblen developed deep-seated interests in evolutionary thinking. Darwin's Origin was published in 1859, close to the times of their respective births, and this monumental work appears to have added to the intellectual environment (or episteme) that influenced both of these thinkers over their decades of inquiry.

Kropotkin based his interests in evolutionary thought on his years of attending university lectures that were interspersed with and later followed with extensive travel and fieldwork in geology, geography, as well as biology and botany. Kropotkin relates that his fundamental insights into the importance of mutual aid came while out in the field and while touring in remote parts of northern and eastern Siberia - including the vast territory known as Yakutia. In contrast, Veblen grew up on a family farm. At the undergraduate level he studied Economic Science at Carleton College where John Bates Clark was teaching and proselytizing his marginalist doctrines. With Kropotkin and Veblen starting from such disparate points, would it be possible to identify connections between their thinking regarding what drives economic and social evolution?

\section{FINAL CONSIDERATIONS}

In Veblen and His European Contemporaries, 1880-1940 author Rick Tilman establishes that Veblen read widely and absorbed a range of ideas from the writings of numerous European economists and social scientists. Unfortunately, nothing in Tilman's research suggests that Veblen was reading the ideas coming out of Russia, especially those ideas pertaining to the importation of Darwin's thinking and the various reactions to them. However, since Kropotkin was spending many of his years of exile in London, his published ideas were readily available in the English language just before and after the turn of the $20^{\text {th }}$ century. This span includes the years when Veblen was focused on absorbing readings from a vast array of authors. In our efforts to establish connections between the thinking of Kropotkin and Veblen regarding evolution we cannot help but wonder: was Veblen indeed familiar with and even influenced by Kropotkin's writings, and possibly vice-versa?

Of the few scholars considering the plausible connections, not one has been able to establish the existence of communication between Kropotkin and Veblen. 
Likewise and relatedly, no researcher exploring connections between Kropotkin and Veblen has been able to establish one author citing the other's writings. In his article "Towards a Reconsideration of Social Evolution," John Watkins (1998) explores the two thinkers and remarks that the parallels are indeed there and can be readily drawn. However, Watkins does not note any scholarly interactions.

Likewise, in his article "Veblen and Kropotkin on Human Evolution," William Dugger (1984) compares and contrasts their approaches. But like Watkins, Dugger fails to note any scholarly interactions, and hence measurable influences on each others' thinking.

When considering their commonalities, what Dugger (1984, pp. 971-972) stresses is that both Kropotkin and Veblen sought to advance full blown understandings of social evolution that challenged the positions dominated by those designated as "social Darwinists." Unified around this effort, and challenging fundamental tenets of social Darwinism, these two theorists created frameworks for thinking based upon different categories - that also lead to some notable divergences in thought.

Kropotkin emphasized the on-going continuity in human cooperation that he characterized as exhibiting a presence over the long span of human history. To offer contrast, Dugger (1984, p. 978) emphasizes that for Veblen human beings organized in different types of societies displayed varying characteristics depending upon the era under consideration. For example, in what Veblen introduces as the era of savagery and describes as an epoch in human history when people lived by hunting and gathering, social interaction was characterized by cooperation, certainly within the immediate community. This on-going orientation towards cooperation over a very long term - with the interests of individuals subsumed under the larger demands of group survival - was challenged with the emergence of the era of barbarism. This stage in social evolution is defined by the emergence of agriculture, stationary human settlements oriented towards food production, and the related rise of food surpluses. In Veblen's view, with the rise of agriculture surplus human societies became plagued by divisions, and so in this era of barbarism cooperation was pushed back and took on the character of a latent cultural tendency. Cooperation did not disappear, but tended to be overwhelmed by the emergence of a fierce competition related to the extraction, ownership, and control over surplus. However despite these sorts of categorical differences, both Kropotkin and Veblen unify around their appreciation for cooperation in our societal past, and with expressed hopes for a more cooperative and hence more fruitful and promising future.

Sidney Plotkin coauthored with Rick Tilman The Political Ideas of Thorstein Veblen (2011) and - similar to Watkins and Dugger - also found no scholarly connections between Kropotkin and Veblen's writings on social evolution. In kindly responding to our query, Plotkin (2015) relieved our puzzlement by writing to us: "Of course, Veblen is notorious for not mentioning his sources." We accept Plotkin's words as ambiguous and also containing a hint of a clue. We've taken the liberty to interpret Plotkin's response as underlining that chances are high that Veblen 
was indeed absorbing Kropotkin's writings on social evolution - but not taking care to cite.

While Kropotkin finished life as perhaps the most famous theorists of anarchism in combination with socialist principles the world has ever known - at least to date - he started out his career as a research scientist displaying broad interests in the physical and natural sciences. Lectures of Professor Karl Kessler seem to have inspired his inquiring deeper and deeper into the importance of mutual aid. ${ }^{5}$ His two extensive expeditions to northeastern Siberia led him to recognize how the harshness of climatic conditions could register as the greatest challenge in the struggle for existence. Rather than observing what Darwin had hypothesized, namely that inter- and intra-species competition defined the bitter struggle for existence among members of the animal kingdom, Kropotkin (2006, p. xi) noticed that groupings of species thrived through cooperation. On his visits to human settlements in some of the harshest climatic zones of northern Siberia, Kropotkin likewise noted cooperation and mutual aid as the foundation for communities dealing with the larger struggle for survival against the harshness of climatic conditions.

In contrast to Kropotkin's distinct background based upon physical and natural sciences supported with observations gained while on lengthy expeditions through some of the most remote regions of Siberia and Yakutia, Veblen appears stimulated and motivated - as well as irritated - by what could be regarded as the narrowly based and socially conservative ideas advanced by John Bates Clark. Railing against what he viewed as shortcomings in Professor Clark's approach appears to have goaded his penetrating critique of neoclassical economics that can be found implicitly in his articles and books, but which is particularly poignant in his 1907 article "The Limitations of Marginal Utility" that was published in the Journal of Political Economy.

Clearly Veblen expressed a deep-seated appreciation for cooperation over competition, and he focused his research on problems of the capitalistic system, especially when it became dominated by large-scale business enterprises that placed under private ownership the collective legacy of knowledge, crafts, and practices. Veblen was irked that the long legacy of accumulated technical and process knowledge that was integral to the public domain and had been supported by collective advancements over the course of human history - came under the ownership of businessmen. Veblen's The Theory of Business Enterprise [1904] stresses a wide array of problems arising when business interests come to dominate production,

\footnotetext{
${ }^{5}$ Georgievsky and Khakhina (1996,) teach us that Kessler and Kropotkin's relationship was that of senior professor (Kessler) and earnest student (Kropotkin). Though Kropotkin responded so favorably and then worked tirelessly to strengthen Kessler's original position on the importance of mutual aid as factor of evolution, still the two held fundamentally different political views. Kessler could be categorized as a liberal, while Kropotkin remains widely known as a rebel and even as a revolutionary and anarchist. However, in spite of their differing views, both struggled against critics to establish the importance of mutual aid. Georgievsky and Khakhina (1996, p. 91) note that mutual aid should be considered as "[...] an important contribution in the world's treasury of evolutionary ideas."
} 
including when vendibility - connected to the narrow interests of profitability overtakes serviceability of output. In Veblen's view, in the era of big business the businessman operates with a narrow orientation towards pecuniary gain, and in so doing prevents the engineers from achieving efficiency gains in industrial production.

In conclusion we would like to note that, similar to other authors considering connections between Kropotkin and Veblen, we also fail to find solid evidence of a verifiable interaction. However, while we can note some differences in emphasis in approach between these two thinkers, we can also note that the thrusts of their contributions also tend to harmonize - and nicely. This harmony is especially evident as both thinkers stress that cooperation has led human societies to grand achievements, certainly in the past, and that a revival of cooperation offers human societies yet a more promising future.

\section{REFERENCES}

Avrich, Paul (1999) Anarchist Portraits. Princeton, NJ: Princeton University Press.

Chernyshevsky, N. G. (1886) (Staryi Transformist.) "Proiskhozhdenie teorii blagotvornosti bor'by za zhizn'." [ The origin of the theory of the struggle for life] Russkaya mysl', [Russian thought] no. 9, sec. 2, pp. 79-114. (in Russian)

Danilevsky, N. (1885-89) Ia. Darvinizm: kriticheskoe issledovanie. [Darwinism: critical examination]. 2 vols. St. Petersburg: Gosudarstvennaya tipografiya (State Printing House). (in Russian)

Danilevsky, N. Ia. (1888) Rossiia i Evropa. [Russia and Europe]3rd ed. St. Petersburg: Tipografiya brat'ev Panteleevykh, [Publishing House of Panteleev brothers]. (in Russian)

Darwin, Charles P. (1871) The Descent of Man, and Selection in Relation to Sex. London: John Murray. Albemarle Street.

Darwin, Charles. (1859 [1979]) The Origin of Species. New York: Gramercy Books.

Dugger, William M. (1984) "Veblen and Kropotkin on Human Evolution," Journal of Economic Issues, 18 (4): $971-985$.

Gall, Yakov M (1976) Bor'ba za Sushchestvovanie kak Factor Evoliutsii Istoriko-Kriticheskiy Analiz Otechestvennykh Botanicheskikh Issledovaniy. [The Struggle for Existence as a Factor of Evolution: Historical and Critical Analysis of Russian National Botanical Research]. Leningrad: Nauka [Science]. (in Russian)

Georgievsky, Alexandr B. and Khakhina, Liya N (1996) Razvitie Evolutsionnoy Teorii v Rossii [The Development of Evolutionary Theory in Russia]. St.-Peterburg: Politeknika-servis. (in Russian)

Kessler, Karl (1880) O Zakone Vzaimopomocschi. Trudy Sankt-Peterburgskogo Obshchestva Estestvoispytatelei. (On the law of mutual aid. In: Memoirs of the St. Petersburg Society of Naturalists). Vol. XI, pp.124-136. (in Russian)

Kolchinsky Eduard (2014) Edinstvo Evolyuzionnoi Teorii V Razdelennom Mire XX Veka [Evolutionary Theory Unity in the XX Century Divided World]. Saint Petersburg: Nestor-Historia. (in Russian]

Kropotkin, Peter (1902 [2006] Mutual Aid: A Factor of Evolution. New-York: Dover Publications, Inc. Lima, Iara Vigo de (2010) Foucault's Archeology of Political Economy. Houndmills, UK: Macmillan.

Malthus, Thomas Robert (1798) An Essay on the Principle of Population. London: St. Paul's Church-Yard.

Marshall, Alfred (1890) Principles of Economics: An Introductory Volume. London: MacMillan.

Nozhin, N. D. (1866) "Nasha nauka i uchenye.” [Our science and teaching] Knizhnyi vestnik, [Book herald] no. 7, pp. 173-78. (in Russian) 
Plotkin, Sidney and Tilman, Rick (2011) The Political Ideas of Thorstein Veblen. New Haven: Yale University Press.

Plotkin, Sidney (2015) E-mail correspondence with John Hall, April 22.

Pogodin, Mikhail (1873) Prostaia Rech' O Mudrenykh Veshchakh [Simple Speech About Abstruse Things]. Moscow: Tipografiya V. M. Frish, [V.M Frish Publishing House]. (in Russian)

Rachinsky, S. A. (1863) “Tsvety i nasekomye.” [Flowers and insects] Russkii vestnik [Russian Herald], no. 1, pp. 347-96. (in Russian)

Sorokin, Pitirim A. (1963). Modern Historical and Social Philosophies. New York: Dover.

Smith, Adam (1776 [1937]) An Inquiry into the Nature and Causes of the Wealth of Nations. London: McMillan.

Tagliagambe, Silvano (1983). "Darwin in Russia and Galileo's trial”. Scientia, an. 77, v. 118, pp. 221266.

Tilman, Rick (2011) Veblen and His European Contemporaries, 1880-1940: A Study of Contemporary Sociologies. Lewiston, N.Y.: The Edward Mellen Press.

Todes, Daniel P (1989) Darwin Without Malthus: The Struggle for Existence in Russian Evolutionary Thought. New York: Oxford University Press.

Veblen, Thorstein (1898) "Why is economics not an evolutionary science?" Quarterly Journal of Economics 12 (4): 620-636.

Veblen, Thorstein (1907) “The limitations of marginal utility". Journal of Political Economy 17 (9): 620-636.

Veblen, Thorstein. (2005) [1904] The Theory of Business Enterprise. Old Chelsea Station, New York: Cosimo.

Vučinich, Alexander (1989) Darwin in Russian Thought. Berkeley: University of California Press.

Watkins, John P. (1998) "Towards a reconsideration of social evolution: Symbiosis and its implications for economics", Journal of Economic Issues 31 (1): pp. 87-105.

Zavadsky, Kirill M. (1973). Razvitie Evolutsionnoy Teorii Posle Ch. Darvina (1859-1920-e gody) [The Development of Evolution Theory after Ch. Darwin (1859-1920's]. Leningrad: Nauka [Sceince]. (in Russian) 